\title{
Optimum Geometry in Sub-Milli-Size Test Machine
}

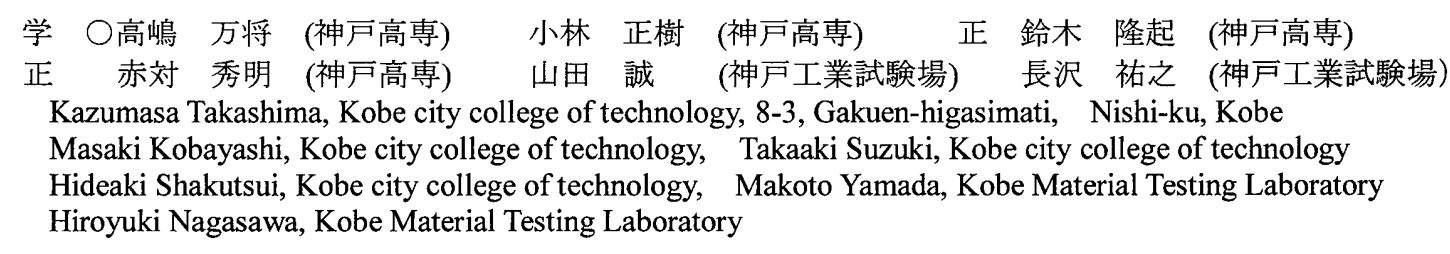

\section{1 緒言}

自動車部品, 発電用高温部品等の材料強度試験では, 実機 プラントや実部品(以下, 実機)から切り出した試験片を用い た破壊試験を行う。その中で, 実機の継続使用やコスト削減 のため, 切り出す試験片サイズの小型化が望まれている ${ }^{(1)}$. しかし，現在サブミリサイズオーダー以下の試験片を対象と する試験法は確立されていない. そこで, 材料強度試験の中 で, 直径 $1 \mathrm{~mm}$ 程度の試験片を用いたサブミリサイズクリー プ試験機の開発が行われている.

一般的なクリープ試験機においては，試験片表面の酸化に よる応力変化防止のため, 試験機内空気は不活性ガスにより 置換される．特に，試験片がサブミリサイズオーダーの場合 には，酸化膜による試験片一の影響が大きいため，開発中の 試験機においても，同様の不活性ガスによる酸化対策が行わ れている. しかし, 試験片周辺で酸化膜の形成が確認されて おり，一般的なクリープ試験機と同様の条件や，置換法を適 用することはできない.

そこで本研究では, 酸化膜の形成が試験機内部や試験片周 辺におけるガスの流動状況に起因すると仮定し, 試験片周り の可視化および数值解析によって本試験機内の流動状況を明 らかにするとともに，開発中のサブミリサイズクリープ試験 機に適する内部形状の検討を行う。

\section{2 実験および解析方法}

Fig.1 に実験装置の概略図を示す、試験片は，円筒ケーシ ング内に，上・下支持部(丸棒)にネジ固定されており，ケー シング下部より不活性ガスを流入させる構造となっている. 試験片は直径 $d=1 \mathrm{~mm}$, 長さ $l=16 \mathrm{~mm}$, 円筒ケーシング内径は $D=17.5 \mathrm{~mm}$ である.

Fig. 2 に本研究で対象とした 3 種類の試験片形状を示す. (a) は酸化膜が生成した標準型，(b)は上下支持部に $R 10$ の丸みを つけた R 型，(c)は下支持部に流路を狭めるキャップを取り付 けたキャップ型である. 本実験では可視化にレーザーライト

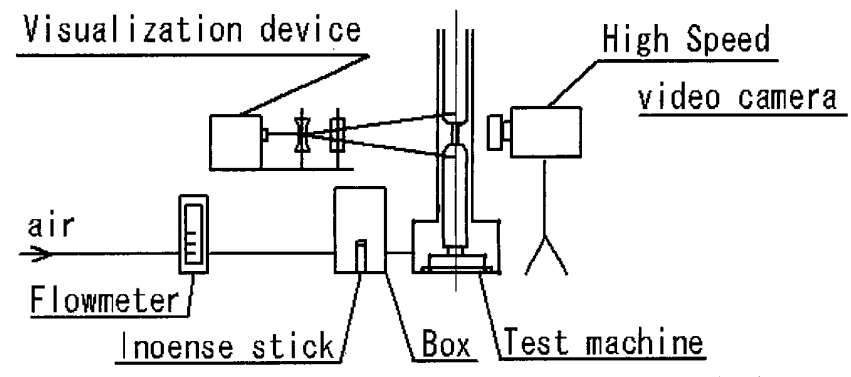

Fig.1 Visualization system by laser light sheet method
シート法を用い, 高速度ビデオカメラ $(250 \mathrm{fps})$ で試験片周辺を 撮影した。 なお, 作動流体は空気(煙)であり,レイノルズ数 は $1 \leqq R e \leqq 16$ である。

数值解析には OpenFOAM を用い, 3 次元非定常 · 非圧縮層 流解析を行った。

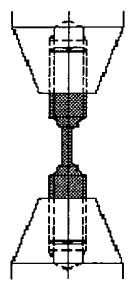

(a) Standard type

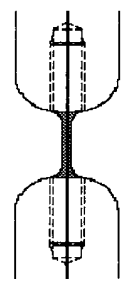

(b) R type

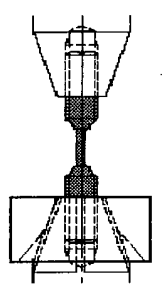

(c) Cap type
Fig.2 Geometry of test piece

\section{3 実験結果および解析結果}

Fig.3にレイノルズ数 $R e=15$ の場合のキャップ型における流 れ場を示す. (a)は可視化実験で撮影した画像から PIV 処理に より得た速度べクトルを示している. (b)は数值解析により得 た流線を示している. 解析結果と実験結果は良好に一致した. どちらも試験片周辺で比較的大きな渦が発生しており，これ が試験片周辺でのガス置換に寄与していると考えられる.

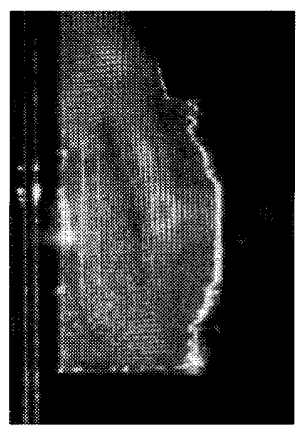

(a) Velocity vector in experimen

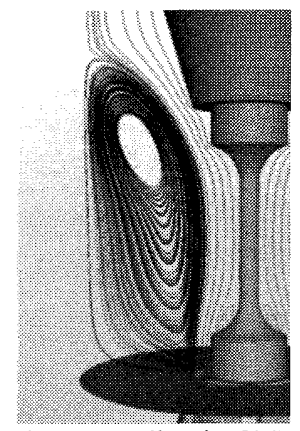

(b)Stream line in CFD
Fig.3 Comparison of flow field around test piece

\section{4 結言}

（1）流入口形状は試験片周辺の流れ場に影響を与えない.

(2) 標準型および $\mathrm{R}$ 型では試験片周辺の角部に起因する速度 低下部が酸化膜形成の原因となることが考えられる.

(3) 速度低下部を減少させるにはキャップ型が有効である.

\section{参考文献}

(1) 野中 勇, “微小サンプルクリープ試験による高温機器寿 命の評価”, 溶接学会誌, Vol.75(2006), pp. 478-481. 